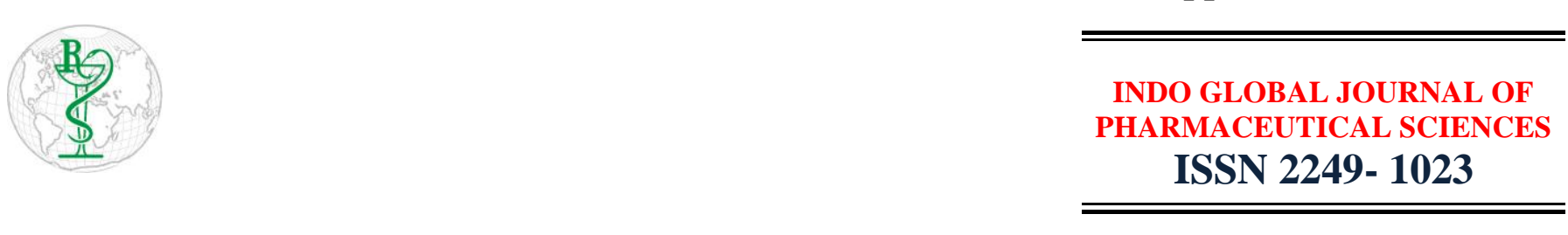

\title{
Withania somnifera- A Boom for Cancer Patients
}

\author{
Ravideep Singh ${ }^{* 1}$, Pooja Sharma ${ }^{1,2}$, Dinesh Kumar ${ }^{1}$ \\ ${ }^{1}$ Sri Sai College of Pharmacy, Manawala, Amritsar-143115, Punjab, India \\ ${ }^{2}$ Department of Pharmaceutical Sciences and Drug Research, Punjabi University Patiala, Punjab, India
}

Address for Correspondence: Ravideep Singh; dineshkumargndu@gmail.com

Received:

01.03.2019

Accepted:

25.03.2019

Keywords

Herbal Medicine;

Natural Product;

Anti-Cancer

Agent.
ABSTRACT: Cancer is one of the major problems affecting public health worldwide. As other cultures, the populations of the Near East rely on medicinal herbs and their preparations to fight cancer. Withaferin A (WA), a steroidal lactone derived from a medicinal plant (Withania somnifera), Withaferin A (WFA), a withanolide derived from medicinal plant Withania somnifera, possesses anti-tumor genic and immunomodulatory activities against various cancer cells. Among the multiple antioxidant molecules determined, antioxidants SOD2, SOD3, Prdx-1 was obviously upregulated by WFA Withania somnifera extracts are known for their anti-cancerous, anti-inflammatory and antioxidative properties. One of their mechanisms of actions is to modulate mitochondrial function through increasing oxidative stress.(C) 2019 iGlobal Research and Publishing Foundation. All rights reserved.

Cite this article as: Singh, R.; Sharma, P.; Kumar, D. Withania somnifera- A Boom for Cancer Patients. Indo Global J. Pharm. Sci., 2019; 9(2Suppl.): 126. DOI: http://doi.org/10.35652/IGJPS.2019.92S24 .

Indo Global Journal of Pharmaceutical Sciences( ISSN 2249 1023; CODEN- IGJPAI; NLM ID: 101610675) indexed and abstracted in CrossRef (DOI Enabling), UGC CARE Journal List, EMBASE(Elsevier), National Library of Medicine (NLM) Catalog, ResearchGate, Publons, CAS (ACS), Index Copernicus, Google Scholar and many more. For further details, visit http://iglobaljournal.com

This is a special issue as an outcome of 'RAPSCON-2019' sponsored by APTI and organized by Sri Sai College of Pharmacy, Manawala, Amritsar, Punjab, India. Relaxation offered in journal format. 